\title{
Presencia de minerales poco comunes en la roca alterada de un edificio medieval escocés colonizado por organismos biológicos
}

\author{
The occurence of rare minerals on decayed medieval \\ Scottish building stone colonised by biological growths
}

M.S.JONES ${ }^{\star}$, R. D. WAKEFIELD, G. FORSYTH ${ }^{* *}$

* Roslyn Associates, ** Opto-Electronics Research Centre, School of Applied Sciences. The Robert Gordon University

Fecha de recepción: 3-XI-98

Aberdeen

Fecha de aceptación: 19-VII-99

$\operatorname{ESCOCIA}($ U.K.)

\section{RESUMEN}

En el transcurso de un estudio sobre el biodeterioro existente en el 'Hermitage Castle', localizado en los 'Scottish Börders' (frontera entre Escocia e Inglaterra), se detectó la presencia de monohidrocalcita, nesquehonita y dipingita, minerales considerados como poco frecuentes, asociados con la colonización biológica presente, especialmente en el caso de la monohidrocalcita y el alga verde Trentepohlia aurea. En este trabajo se presenta una revisión bibliográfica sobre estos minerales así como la teoria del posible origen biogénico de la monohidrocalcita.

\section{SUMMARY}

During the course of a study of biodeterioration at Hermitage Castle in the Scottish Borders various rare minerals: monohydrocalcite, nesquehonite and dypingite were found in association with the biological growths. Monohydrocalcite was found particularly in association with a green alga "Trentepohlia aurea". A brief review of previous publications concerning these minerals is given and the theory put forward with regard to the possible origin of the monohydrocalcite as a biogenic by product.

\section{INTRODUCCIÓN}

El 'Hermitage Castle' fue seleccionado como objeto de este estudio debido a que el deterioro que presenta la roca con la que está construido parece estar causado por una especie del alga Trentepohlia que es la dominante en el momumento. En el transcurso de la investigación se identificaron, tanto en el exterior como en las paredes ruinosas del interior del castillo, varios minerales geológicamente poco comunes. Así, mientras que en el exterior se detectó la presencia de monohidrocalcita, en el interior los minerales identificados fueron nesquehonita y dipingita.

En este trabajo se presenta una descripción de estos minerales así como una discusión sobre la información

\section{INTRODUCTION}

Hermitage Castle was originally chosen as a case study for this work because an algal species of Trentepohlia, prevalent on the castle appeared to be causing stone decay. During the course of the investigation various geologically rare minerals were found both outside the castle and on the inner ruinous walls. The minerals found on the exterior were identified as monohydrocalcite, and on the interior as nesquehonite and dypingite.

A description of these minerals is presented here along with a discussion of information on other 
que hasta el momento se ha publicado acerca de ellos. Aunque existen varios trabajos publicados sobre este castillo, además de un informe (1-3), el presente estudio ofrece una caracterización más detallada de la roca, información geológica y discute la relación de estos minerales con $\mathbf{T}$. aurea y con otros organismos colonizadores del castillo.

\subsection{Información histórica y geográfica}

El 'Hermitage Castle', actualmente a cargo del 'Historic Scotland', está localizado en la frontera entre Escocia e Inglaterra (Newcastleton Parish, Roxburghshire, Scottish Borders), en un apartado valle fluvial, rodeado por vegetación de tipo brezal. Este castillo, después de su fortificación, fue muy importante en la Guerra de la Independencia entre Escocia e Inglaterra. En el siglo XV le añadieron cuatro grandes torres. Rodeada por restos arqueológicos aún no investigados, esta impresionante ruina está limitada al sur por el río 'Hermitage Water' (a $15 \mathrm{~m}$ del castillo), con cuyas aguas se llenaron los fosos defensivos. En los años 30 el castillo pasó de la familia Buccleuch al 'HM Office of Works', el actual 'Historic Scotland'.

\subsection{Información previa sobre la colonización biológica presente en el castillo}

Si se observa el castillo, por su cara norte, desde una distancia de 10 metros, ésta parece estar construida con arenisca roja; sin embargo, un examen a una distancia más corta revela que esta coloración roja (o naranja, según la época del año y la humedad de la roca) es debida a un alga que coloniza tanto la arenisca como el mortero. Este alga, con aspecto de masa granular que engloba granos de arenisca en la roca y aspecto de pequeños terrones $(<3 \mathrm{~mm})$ en el mortero, fue identificada en el 'Natural History Museum' de Londres como Trentepohlia aurea (3) y se caracteriza porque los filamentos algales contienen células llenas con un aceite pigmentado por un carotenoide naranja que se acumula en respuesta a la intensidad luminosa y a la deficiencia de nitrógeno (4).

T. aurea es responsable de alteraciones de tipo físico ya que los filamentos algales, de hasta $20 \mu \mathrm{m}$ de diámetro, provocan el desprendimiento de los granos minerales dando lugar a la desestabilización de la superficie de la roca, la cual acaba desprendiéndose en forma de escamas de hasta $5 \mathrm{~mm}$ de espesor. Cuando ocurre esta descamación la superficie de la roca que queda a la vista suele presentar un color verde intenso.

El examen de las muestras rocosas mediante microscopio electrónico de barrido (SEM) puso en evidencia que mientras que la superficie exterior de la roca estaba casi published occurrences. Previous publications have discussed the biodeterioration at Hermitage Castle to date (1-3) however this paper presents more detail on stone characterisation, geological information and discusses the occurrence of these rare minerals with $\boldsymbol{T}$. aurea and other biological growths at the castle.

\subsection{Historical and locational information}

Hermitage Castle, currently in the care of Historic Scotland, is situated in the Newcastleton Parish of Roxburghshire in the Scottish Borders, in a remote river valley surrounded by moorland. The castle, after fortification, became prominent in the Wars of Independence between Scotland and England. Four massive towers were added in the 15th Century. Surrounded by uninvestigated earthworks, this impressive ruin is bounded by Hermitage Water, which runs to the south of the castle (15 $\mathrm{m}$ away) and was used to fill a series of ditches to act as defense. The castle passed from the Buccleuch family to HM Office of Works in the 1930's and thence to Historic Scotland.

\subsection{Background information on biological growths found at the castle}

From a distance of $10 \mathrm{~m}$, the walls of the castle on the north face appear to be composed of red sandstone. It is only on closer examination that one sees the colouration is attributable to an algal growth which varies from red to orange depending on the time of year and wetness of stone. The alga was well established on both sandstone and mortar and appears as a granular mass integral with surface sandstone grains, and as small $(<3 \mathrm{~mm})$ clumps on the mortar. Under light microscopy the alga responsible for the orange colouration of the stone surface was verified by the Natural History Museum in London as Trentepohlia aurea (3). The algal filaments contain cells filled with an orange carotenoid oil accumulated in response to light intensity and nitrogen deficiency (4).

T. aurea causes physical decay whereby algal filaments up to $20 \mu \mathrm{m}$ in diameter force apart individual grains and so destabilise the stone surface which falls away from the underlying stone as a spall, typically up to $5 \mathrm{~mm}$ deep. The undersurface of the stone once the spall has fallen away is vivid green in colour.

Examination of stone samples by scanning electron microscopy (SEM) showed the upper stone surface to be colonised almost exclusively by $T$. aurea, found 
exclusivamente colonizada por T. aurea, localizada entre los granos minerales, la superficie inferior de las escamas desprendidas presentaba una comunidad microbiana mucho más compleja compuesta, además de por células y filamentos algales, por algas verde-azuladas tales como Nostoc, por bacterias y por hongos, estando todo ello inmerso en un mucílago transparente (2).

La zona en la que se localiza el castillo (Scottish Borders) es una de las áreas de Escocia que recibe más cantidad de lluvia, con una precipitación media total anual de 1.550 $\mathrm{mm}$ (Scottish Meteorological Office), lo cual, unido al hecho de que las paredes interiores del castillo están expuestas a la intemperie por su parte superior, y a la situación abrigada en la que se encuentra el castillo, origina que las paredes permanezcan húmedas durante largos períodos de tiempo. En consecuencia, mientras que las paredes interiores presentan una exhuberante colonización debida a algas verdes, estos organismos son poco frecuentes en las paredes exteriores siendo sin embargo importante en ellas la colonización debida a líquenes (1).

En el transcurso de este estudio sobre biodeterioro, se identificaron varios minerales, considerados como no frecuentes, asociados con T. aurea. Se presenta aquí una descripción de estos minerales así como la relación de $\mathbf{T}$. aurea con la monohidrocalcita.

\section{METODOLOGÍA. RECOGIDA Y PREPARACIÓN DE LAS MUESTRAS Y TÉCNICA'S ANALÍTICAS}

Se tomaron muestras, con la ayuda de un bisturí, de una costra blanquecina que cubría importantes áreas de la pared interior norte de la torre noroeste (siglo XV) para su posterior análisis químico y microscópico. Debido a la antiguedad del monumento no fue posible obtener muestras grandes de piedra de esta zona, sin embargo, en ese momento la cara este de la torre sudeste se encontraba en fase de restauración lo que permitió tomar muestras del tamaño de un puño en dicha torre. En esta zona la descamación de la arenisca también era evidente, aunque en menor extensión que en la cara norte.

Con el objeto de analizar las muestras mediante microscopía óptica con nicoles cruzados y SEM con energía dispersiva de rayos-X (EDX), se prepararon las muestras en forma de láminas delgadas $(30 \mu \mathrm{m}$ de espesor) cortadas desde la superficie de la roca hasta $50 \mathrm{~mm}$ de profundidad. Como control se prepararon también láminas delgadas de la misma roca pero de una zona más profunda $(150 \mathrm{~mm})$ ya que esto fue lo más cercano a una roca fresca no expuesta que se pudo encontrar. También se examinaron pequeños fragmentos de roca mediante microscopía óptica de fluorescencia. between the stone mineral grains. The microbial community on the underside of the spalled surface was more complex, being made up of single celled and filamentous algae and also blue green algae such as Nostoc, bacteria and fungi all embedded in clear mucilage (2).

The Border area receives one of the highest rainfall counts in Scotland, with a mean total of $1.550 \mathrm{~mm}$ per year (Scottish Meteorological Office). The inner walls of the castle are open to the atmosphere from above and because of their sheltered situation and the high rainfall, remain damp for extended periods of time. Consequently, the inner walls support a lush coverage of green algae. In comparison, the sandstone of the outer walls of Hermitage exhibited very few areas of green algal growth, the surfaces being covered largely by well established lichens (1).

During the course of this study on biodeterioration number of rare minerals were discovered, some in association with $T$. aurea. A description of the minerals is now given and the relationship of $\boldsymbol{T}$. aurea with monohydrocalcite described.

\section{METHODOLOGY. SAMPLING, SAMPLE PREPARATION AND ANALYTICAL TECHNIQUES}

The interior north wall of the $15^{\text {th }}$ Century north west tower contained large areas of a white crustal material. This was examined and samples were easily removed by a scalpel for chemical and microscope analysis. Since Hermitage castle is an ancient monument it was not possible to obtain large pieces of in situ stone however hand sized specimens with $\boldsymbol{T}$. aurea growing on the surface, were obtained from the east face of the south east tower where repair work was being carried out. Spalling of the sandstone was evident though on a much lower total surface area to that observed on the north face.

Samples collected were made into a number of $30 \mu \mathrm{m}$ thick thin sections through the top surface to $50 \mathrm{~mm}$ into the stone, which enabled study by a light microscope with cross polars and a scanning electron microsopy (SEM) with energy dispersive $X$ ray $(E D X)$. Thin sections were also prepared some $150 \mathrm{~mm}$ into the same stone to act as a control, as this was the nearest equivalent to fresh unexposed stone which could be found. Stone grains were also examined by fluorescence microscopy. 
La caracterización de la roca y de los productos de alteración se hizo por fluorescencia de rayos $\mathrm{X}(\mathrm{XRF})$, difracción de rayos $\mathrm{X}(\mathrm{XRD})$ y espectroscopía de infrarrojos mediante la transformada de Fourier (FT-IR). Para los análisis por XRF se empleó un espectrómetro Philips PW1404, según los métodos de Norrish y Hutton para la fusión de la muestra en perlas y reducir el efecto matriz. La caracterización física de la roca y de las escamas se realizó mediante Porosimetría de Mercurio.

Se llevó también a cabo un reconocimiento general del edificio a una altura aproximada de $1,5 \mathrm{~m}$ por encima del nivel del suelo, anotándose la presencia de los distintos organismos (se tomaron muestras y se identificaron), el color de la piedra (relacionado con la mineralogía y el estado de alteración) y los síntomas de alteración; estos datos se analizaron posteriormente utilizando el Test de Chi Cuadrado para detectar la existencia de relaciones significativas entre la presencia o ausencia de los parámetros seleccionados (5).

\section{RESULTADOS. GEOLOGÍA Y CARACTERIZACIÓN DE LA ROCA}

El 'Hermitage Castle' está levantado sobre 'Whita Sandstone', la cual pertenece al grupo inferior de las series de Calizas Carboniferas. Encontrar la cantera original de donde se extrajo la roca empleada en la construcción del castillo fue una ardua tarea, ya que los archivos se destruyeron en un incendio del estado de Buccleuch. Sin embargo, se localizó una pequeña cantera abandonada en la ladera cercana al castillo de la que, según las notas del British Geological Survey, es probable que provenga la roca del castillo, además de del lecho del cercano río 'Hermitage Water'. El castillo estuvo en ruinas en el siglo XVIII, momento en el que se realizó una importante restauración de la parte superior de sus paredes. La roca empleada en esta restauración procedió probablemente de la cantera Corby, cercana a Newcastleton. En una visita realizada en 1995 a esa cantera se observó que T. aurea colonizaba la roca, la cual, aunque en sus características es parecida a la del 'Hermitage Castle', no presenta los mismos síntomas de alteración. Es posible que el origen de T. aurea en el monumento sea la propia cantera, es decir que esta especie llegase hasta el edificio transportada en la piedra utilizada en la restauración.

El 'Hermitage Castle' está construido con arenisca, generalmente sillería, 'partly coursed', que varía en color del blanco al amarillo según la presencia o ausencia de compuestos de hierro. Esta roca está compuesta principalmente por cuarzo y feldespato potásico con trazas de óxidos de hierro, calcita, rutilo, mica, goetita rica en aluminio, illita, clorita y caolinita, todo ello cementado con sobrecrecimientos silíceos (producidos por la presión de la solución en la formación del sedimento). El examen
$X$-ray fluorescence $(X R F), X$-ray diffraction $(X R D)$ and fourier transform infra-red spectroscopy (FT-IR) were used to characterise both the stone and decay products. Analyses by XRF were obtained using a Philips PW1404 spectrometer and the methods of Norrish and Hutton for sample fusion and for corrections for interelement effects. Further physical characterisation of the stone and spall was carried out by Mercury Porosimetry.

A general survey of the castle was undertaken on a course of stones at approximately $1.5 \mathrm{~m}$ above ground level. The presence of biological growths (samples taken and identified), stone colour (related to mineralogy and state of weathering) and decay characteristics was recorded and subsequently manipulated using the Chi Square Test to see if there was a significant relationship between the presence or absence of the chosen parameters (5).

\section{RESULTS. GEOLOGY AND STONE CHARACTERISATION}

Hermitage Castle is situated on the Whita Sandstone, found within the lower border group of the Carboniferous Limestone series. Finding the original source of the stone for the castle was problematic because the records were lost in a fire at the Buccleuch estate. However, a small disused quarry was located on the hillside close to the castle, using notes from the British Geological Survey, and it is likely that the original stone came from here and from the river bed of the nearby Hermitage Water. The castle was in ruins by the 18th Century, when extensive renovations were carried out on the higher part of the castle walls. The likely source of the stone for the repair work was Corby quarry near Newcastleton. On a visit to this quarry in 1995 the alga T. aurea was found growing on stone which was allied in characteristics to that of Hermitage Castle, but displayed no evidence of similar decay. It is possible that the source of $\boldsymbol{T}$. aurea was the quarry and the alga was carried on quarried repair stone, as this alga was not found colonising any other surfaces in the proximity of the building.

Hermitage Castle is built of partly coursed sandstone which varies in colour from whitelyellow depending on the presence or absence of iron . compounds. The overall composition of the stone is of grains of quartz and $K$ feldspar with trace amounts of Fe oxides, calcite, rutile, mica, Al-rich goethite, illite, chlorite and kaolinite, cemented by siliceous overgrowths (produced by pressure solution on formation of the sediment). Examination 
mediante SEM de la roca no colonizada tomada en el 'Hermitage Castle' mostró que ésta presentaba muy poco material cementante, estando los cristales de cuarzo muy próximos entre sí. Se observó también la presencia de algunos depósitos de $\mathrm{Si}, \mathrm{Ca}$ y $\mathrm{Al}$ sobre la superficie de los cristales del cemento silíceo. En cuanto a la porosidad, si bien en la roca fresca es de $15-25 \%$, ésta ha sido modificada en el edificio debido a la colonización biológica y a los procesos de disolución/reprecipitación de los elementos minerales, tanto en el interior de la roca como en los alrededores del mortero de cal.

Se encontraron grandes agujeros, de tamaño variable, entre 5 y $50 \mathrm{~mm}$, algunos de los cuales contenían illita verde (datos obtenidos mediante XRD). Probablemente, esta arcilla también estuvo en algun momento presente en aquellos huecos en los que ahora no aparece, siendo la propia alteración la causante de su desaparición. Mediante fluorescencia de rayos X se analizaron muestras de escamas, roca fresca y mortero; los resultados se muestran en la Tabla 1. Mientras que la roca fresca, tanto la blanca como la amarilla, contienen una media de $0,34 \%$ de $\mathrm{Ca}$, las escamas de la fachada norte de la torre noroeste presentan un porcentaje de $\mathrm{Ca}$ que varía entre 0,90 y $2,02 \%$.

\subsection{Mortero}

Se trata de un mortero de cal de grano grueso (Tabla 1) compuesto principalmente por un $60 \%$ de árido silíceo, un $18 \%$ de carbonato y un $10 \%$ o menos de minerales de $\mathrm{Al}, \mathrm{Mg}, \mathrm{K}$ y $\mathrm{Fe}$. En la roca fresca el magnesio representa un $0,12 \%$ del total, en las escamas un $0,34-0,59 \%$ y en el mortero de las paredes externas del monumento un $3,64 \%$ (en forma de agregados granulares). by SEM of un-colonised stone obtained from Hermitage Castle showed very little cementing material present, and that quartz crystals closely abut one another. Occasional deposits containing Si, $\mathrm{Ca}$ and $\mathrm{Al}$ were seen on the surface of the siliceous cement crystals. The primary porosity was between 15-25\% however this has been modified on the building due to the presence of biological growths and dissolution/reprecipitation of minerals elements both within the stone and surrounding lime mortar.

Large pock marks or holes varying from 5 to $50 \mathrm{~mm}$, some containing green illite clays, were found on the building (XRD data). The holes without clay, may have contained similar substances which have been weathered out, perhaps in the lifetime of the building. X-ray fluorescence was carried out on a number of samples of spall, fresh samples and mortar and these results can be seen in Table 1. Fresh Hermitage stone (white and yellow) contained on average $0.34 \% \mathrm{Ca}$, whilst samples of spalled stone from the north face of the north west tower contained between 0.90 and $2.02 \% \mathrm{Ca}$.

\subsection{Mortar}

The mortar is coarse grained lime mortar (Table 1) and is composed mainly of $60 \%$ silicate aggregate with $18 \%$ carbonate, and $10 \%$ or less $\mathrm{Al}, \mathrm{Mg}, \mathrm{K}$ and $\mathrm{Fe}$ containing minerals. Magnesium is present in the fresh stone at $0.12 \%$, in the spall from $0.34-0.59 \%$ and in mortar taken from the outer surface of the building $\mathrm{Mg}$ represents $3.64 \%$ (present in aggregate grains within the mortar).

\section{TABLA 1 (TABLE 1)}

Resultados de fluorescencia de Rayos X, de muestras de piedras colonizadas y no colonizadas, provenientes del Hermitage Castle y del Corby Quarry. El mortero se da como material de referencia.

(X-Ray fluorescence data of fresh and colonized stone samples from Hermitage Castle and Corby Quarry. Mortar is given for comparison).

\begin{tabular}{|c|c|c|c|c|c|c|c|c|c|c|c|}
\hline & $\begin{array}{l}\text { Arenisca } \\
\text { blanca } \\
\text { control } \\
\text { (White sst } \\
\text { control) }\end{array}$ & $\begin{array}{l}\text { Amarillo sst } \\
\text { control } \\
\text { (Yellow sst } \\
\text { control) }\end{array}$ & $\begin{array}{c}\text { Arenisca de } \\
\text { cantera } \\
\text { blanca } \\
\text { (Quarry sst } \\
\text { white) }\end{array}$ & $\begin{array}{c}\text { Escama } \\
\text { (Spall) } \\
\text { (N1) }\end{array}$ & $\begin{array}{c}\text { Escama } \\
\text { (Spall) } \\
\text { (N2) }\end{array}$ & $\begin{array}{l}\text { Escama } \\
\text { (Spall) } \\
\text { (N3) }\end{array}$ & $\begin{array}{l}\text { Escama } \\
\text { (Spall) } \\
\text { (4) }\end{array}$ & $\begin{array}{c}\text { Escama } \\
\text { (Spall) } \\
\text { (N5) }\end{array}$ & $\begin{array}{c}\text { Escama } \\
\text { (Spall) } \\
\text { (S1) }\end{array}$ & $\begin{array}{c}75 \mathrm{~mm} \\
\text { en mortero } \\
75 \mathrm{~mm} \\
\text { in mortar }\end{array}$ & $\begin{array}{c}\text { Mortero } \\
\text { exterior } \\
\text { (Monar } \\
\text { face) }\end{array}$ \\
\hline $\mathrm{SiO}_{2}$ & 96,10 & 94,00 & 94,40 & 92,40 & 91,90 & 92,00 & 93,40 & 92,20 & 92,50 & 73,00 & 58,50 \\
\hline $\mathrm{TiO}_{2}$ & 0,07 & 0,19 & 0,12 & 0,14 & 0,32 & 0,22 & 0,27 & 0,21 & 0,20 & 0,53 & 0,64 \\
\hline $\mathrm{Al}_{2} \mathrm{O}_{3}$ & 1,51 & 2,47 & 3,64 & 2,16 & 2,95 & 2,64 & 2,43 & 2,47 & 3,21 & 8,66 & 10,30 \\
\hline $\mathrm{Fe}_{2} \mathrm{O}_{3}{ }^{*}$ & 0,17 & 0,59 & 0,41 & 0,29 & 0,36 & 0,14 & 0,18 & 0,25 & 0,17 & 4,26 & 5,32 \\
\hline $\mathrm{MnO}$ & $<0,01$ & 0,01 & $<0,01$ & $<0,01$ & 0,01 & $<0,01$ & 0,01 & 0,01 & 0,01 & 0,09 & 0.07 \\
\hline $\mathrm{MgO}$ & 0,12 & 0,12 & 0,11 & 0,47 & 0,52 & 0,48 & 0,34 & 0,59 & 0,42 & 2,21 & 3,64 \\
\hline $\mathrm{CaO}$ & 0,35 & 0,33 & 0,01 & 1,44 & 1,51 & 1,90 & 0,90 & 2,02 & 1,10 & 7,91 & 18,23 \\
\hline $\mathrm{Na}_{2} \mathrm{O}$ & $<0,10$ & $<0,10$ & $<0,10$ & $<0,10$ & $<0,10$ & $<0,10$ & $<0,10$ & $<0,10$ & $<0,10$ & 0,55 & 0,95 \\
\hline $\mathrm{K}_{2} \mathrm{O}$ & 1,08 & 1,78 & 0,83 & 1,54 & 1,82 & 1,83 & 1,45 & 1,68 & 1,96 & 2,04 & 1,89 \\
\hline $\mathrm{P}_{2} \mathrm{O}_{5}$ & 0,17 & 0,12 & 0,01 & 0,17 & 0,28 & 0,27 & 0,17 & 0,28 & 0,11 & 0,13 & 0,17 \\
\hline SUM & 99,57 & 99,61 & 99,53 & 98,61 & 99,67 & 99,48 & 99,15 & 98,71 & 99,68 & 99,38 & 99,71 \\
\hline LLOI & 0,41 & 0,74 & 1,76 & 8,36 & 8,68 & 15,24 & 9,49 & 9,50 & 11,18 & 8,21 & 15,43 \\
\hline
\end{tabular}

${ }^{*} \mathrm{Fe}$ total como $\mathrm{Fe}_{2} \mathrm{O}_{3}$. La precisión es de $+/-1 \%$ sobre la cantidad total $(>0,1 \%)$, excepto para los elementos más ligeros con el $\mathrm{Mg}$ en donde la precisión es de $=1-5 \%\left({ }^{*} \mathrm{Total} F e\right.$ as $\mathrm{Fe}, \mathrm{O}$, . Accuracy is $+/-1 \%$ of the known amount $(>0.1 \%)$, except for lighter elements such as $\mathrm{Mg}$ where figures are $=1-5 \%$ )

$\mathrm{LOI}=$ Pérdida a fuego a $1.000^{\circ} \mathrm{C}$ (LOI = Loss on ignition at $\left.1.000^{\circ} \mathrm{C}\right)$

sst $=$ arenisca (sst $=$ sandstone)

Los análisis se obtuvieron a través de fluorescencia de Rayos X, utilizando un espectómetro Philips PW404 y los métodos de Norrish y Hutton (1969) para la fusión de la muestra de Fe $\mathrm{O}_{3}$ y para las correcciones de efectos inter-elemento. Los resultados fueron proporcionados por Dereck C. Bain, Macaulay Land Use Research Institute, Aberdeen (Analyses were obrained by X-ray fluorescence spectrometry using a Philips PWI404 spectrometer and the meihods of Norrish and Hutton (1969) for sample fusion and for corrections for inter-element effects. Results provided by Derek C. Bain, Macaulay Land Use Research Institute. Aberdeen) 


\subsection{Productos de alteración en las paredesexteriores: monohidrocalcita}

La monohidrocalcita es un mineral muy poco frecuente en el ambiente geológico, siendo ésta la primera vez que se cita su presencia en muestras tomadas en edificios. Este mineral, la monohidrocalcita, identificado mediante XRD y FT-IR (Figura 1), se encontró en muestras de la superficie externa de la roca (escamas) colonizadas por T. aurea. El análisis de las escamas mediante XRF mostró que estaban constituidas hasta un $2 \%$ por $\mathrm{CaO}$, y su examen mediante SEM con microsonda acoplada (EDX) reveló que sobre toda la muestra se distribuían concreciones minerales de $5-10 \mu \mathrm{m}$ de largo formadas por cristales individuales de monohidrocalcita de tamaño $<1 \mu \mathrm{m}$ (Figura 2). El estudio de las secciones finas de la superficie exterior de las escamas permitió observar la presencia de células algales y de monohidrocalcita localizadas entre las dos partes de un cristal de feldespato potásico partido por la mitad (Figura 3 ), constituyendo los planos de exfoliación de los cristales de feldespato potásico alterados un nicho ecológico para las algas, tal y como se pudo corroborar con SEM.

El análisis de la porosidad mediante porosimetría de mercurio indicó que en las escamas ocurre un importante incremento de la porosidad, ya que mientras que su valor en la roca fresca es de $14,23 \%$, en las escamas es de $28,14 \%$; además, hay que tener en cuenta que la presencia de materia orgánica en las escamas impide determinar la porosidad real por lo que ésta podría ser mayor. En cuanto a la distribución del tamaño de poro, ésta es de $20-50 \mu \mathrm{m}$ en la rocă fresca no colonizada y de $1-500 \mu \mathrm{m}$ en las escamas, indicando cambios estructurales en la roca

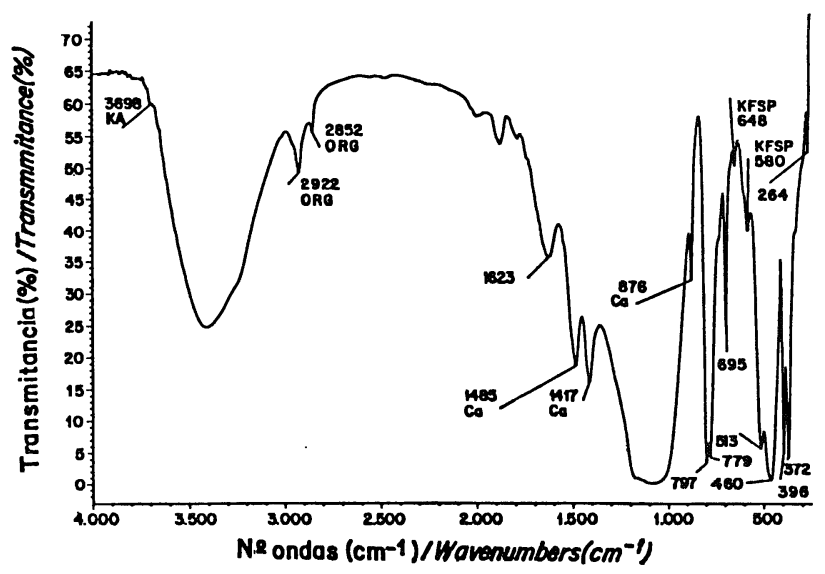

Figura 1.- Espectro de FT-IR de la arenisca con escamas del Hermitage Castle. Ca representa a un polimorfo metaestable de caliza: vaterita o, más probablemente, monohidrocalcita. KFSP representa un feldespato cálcico, KA es caolinita y ORG son orgánicos. Los restantes picos corresponden al cuarzo.

Figure 1.- FT-IR of spalled sandstone from Hermitage Castle. Ca represents a metastable polymorph of calcite: vaterite or more likely monohydrocalcite. KFSP represents $K$ feldspar, $K A$ is kaolinite and $O R G$ is organics. All other peaks represent quartz.

\subsection{Exterior decay products: monohydrocalcite}

Monohydrocalcite is an extremely rare mineral in the geological environment and the occurrence of this mineral at Hermitage Castle is the first time it has been reported in stone taken from a building. The monohydrocalcite, identified by XRD and FT-IR (Figure 1), was found in samples of external stone (spall) colonised by $T$. aurea. Further XRF analysis indicated up to $2 \%$ of the spall was $\mathrm{CaO}$. The spall, examined by SEM with EDX analysis revealed mineral concretions (5-10 $\mu$ m across) of 'blocky' monohydrocalcite crystals which individually were $<1 \mu \mathrm{m}$ across and distributed over the entire sample (Figure 2). Thin sections of the top surface of the spall (Figure 3) revealed two halves of a dissected $K$ feldspar crystal the interior of which was filled with algal ceils and monohydrocalcite. Single weathered $K$ feldspar crystals from the spalled sandstone when examined by SEM showed cleavage planes that provided a niche for algal growth.

Mercury porosimetry measurements gave the porosity of fresh stone as $14.23 \%$, the spall was measured at $28.14 \%$, representing a substantial porosity increase at the spalled surface. The true porosity of the spall could be greater but is difficult to assess due to the presence of organic material. Pore size distribution in the fresh uncolonised stone obtained from the site was measured at 20-50 $\mu$ m. However the pore size distribution in spalled stone varied from $1-500 \mu m$ indicating textural changes in

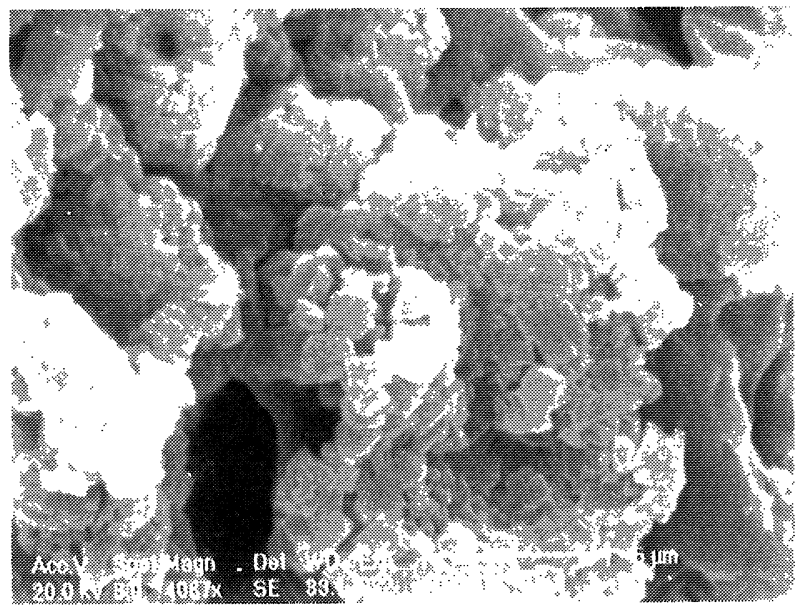

Figura 2.- Microscopía electrónica de barrido con EDX. Concreciones de minerales de $5-10 \mu \mathrm{m}$ de largo formadas por cristales individuales de monohidrocalcita de $<1 \mu \mathrm{m}$, y distribuidas por toda la muestra.

Figure. 2.- Scanning electron microscopy with EDX analysis. Mineral concretions (5-10 $\mathrm{mm}$ across) of monohydrocalcite crystals which individually were $<1 \mu \mathrm{m}$ across and distributed over the entire sample. 
alterada que, posiblemente, hayan sido provocados por la comunidad microbiana.

Por microscopía de fluorescencia se observó gran cantidad de mucílago, comprobándose que la comunidad fotosintética, presente en la roca alterada, es casmoendolítica (se desarrolla en las grietas, entre granos) y probablemente también criptoendolítica (en huecos hechos por ellos mismos sobre los granos) y epilítica (en la superficie).

\subsection{Productos de alteración en las paredes interiores: nesquehonita y dipingita.}

Debido al estado ruinoso de algunas zonas del 'Hermitage Castle', las paredes interiores del castillo están a la intemperie. La pared interior de la torre noroeste presenta una costra blanca y friable, de aproximadamente $5 \mathrm{~m}^{2}$, que se raya fácilmente con la uña, y que en agunas zonas está colonizada por algas verdes. El análisis mediante $\mathrm{XRD}$ de esta costra puso de manifiesto que está compuesta por los minerales nesquehonita $\left(\mathrm{MgCO}_{3} \cdot 3 \mathrm{H}_{2} \mathrm{O}\right)$ y dipingita $\left(\mathrm{Mg}_{5}\left(\mathrm{CO}_{3}\right)(\mathrm{OH})_{2} \cdot 5 \mathrm{H}_{2} \mathrm{O}\right)$ los cuales se presentan, al estudiarlos mediante SEM (Figura 4), en forma de grupos de cristales prismáticos bien desarrollados y de diferentes tamaños (hasta $200 \mu \mathrm{m}$ ), siendo comparables en apariencia a los cristales sintetizados (6).

\subsection{Roca del Hermitage y colonización biológica}

Se realizó un reconocimiento general de la roca empleada en la construcción del 'Hermitage Castle' en todas las fachadas accesibles (la fachada éste se encontraba en ese momento en fase de restauración) a

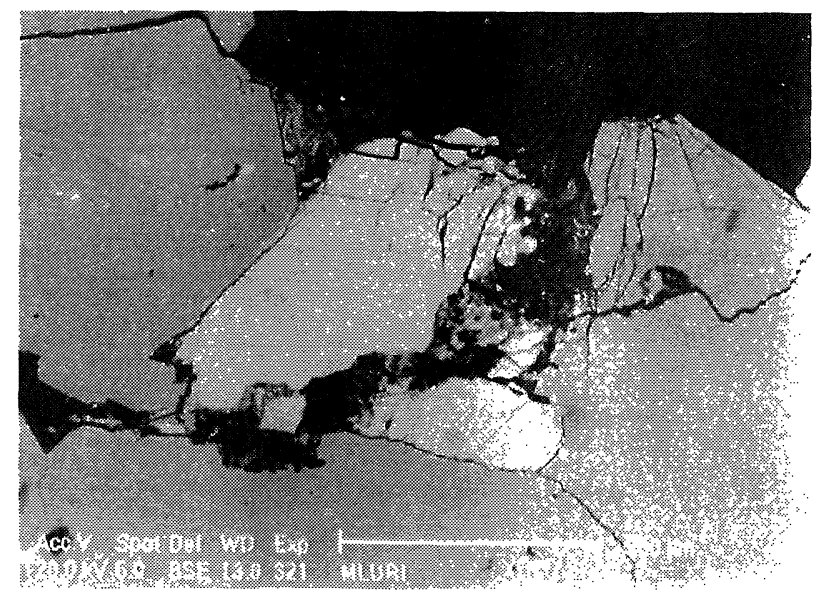

Figura 3.- La sección delgada de la superficie de la escama revela la presencia de dos partes de un cristal de feldespato potásico partido, dentro del cual se observa la presencia de células argales y cristales de monohidrocalcita.

Figure. 3. - Thin sections of the top surface of the spall revealed two halves of a dissected $k$ feldspar crystal the interior of which was filled with algal cells and monohydrocalcite. the decayed stone, possibly attributable to the effects of the microbial community.

Fluorescence microscopy showed the location of the photosynthetic community in decayed stone samples to be chasmoendolithic (in cracks between grains) and probably cryptoendolithic (in self-made pits on grains) as well as epilithic (on the surface). Much mucilage was present.

\subsection{Interior decay products: nesquehonite and dypingite}

Hermitage Castle is partly ruinous and its internal walls were open to the atmosphere. Nesquehonite and dypingite, identified by XRD, were found in large quantities covering approximately $5 \mathrm{~m}^{2}$ of the sandstone of the internal north west tower. The mineral occurred as a white, friable crust which was easily scratched by a fingernail. The crust was covered in places with green algae. The crustal deposit contained crystals of nesquehonite $\left(\mathrm{MgCO}_{3} \cdot 3 \mathrm{H}_{2} \mathrm{O}\right)$ and dypingite $\left(\mathrm{Mg}_{5}\left(\mathrm{CO}_{3}\right)(\mathrm{OH})_{2}\right.$ $\mathrm{SH}_{2} \mathrm{O}$ ). Scanning Electron Microscopy (Figure 4) showed the bundles of prismatic crystals to be well developed and varied in size, up to $200 \mu \mathrm{m}$, and compared to synthesised crystals in appearance (6).

\subsection{Hermitage stone and biological growths}

During a survey of stone in Hermitage Castle observations from all accessible facades of the castle (east face, under repair) at approximately $1.57 \mathrm{~m}$ above ground level were taken using parameters

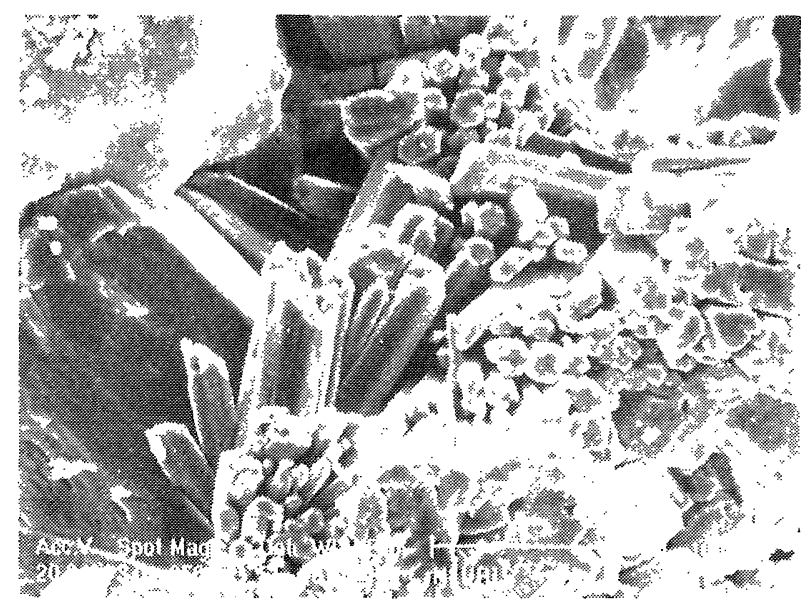

Figura 4.- Microscopia electrónica de barrido. Nesquehonita, grupo de cristales prismáticos bien desarrollados y de diferentes tamaños, hasta 200 $\mu \mathrm{m}$

Fig. 4. - Scanning electron microscopy. Nesquehonite, the bundles of prismatic crystals appear well developed and vary in size, up to $200 \mu \mathrm{m}$. 
una altura aproximada de $1,57 \mathrm{~m}$ por encima del nivel del suelo, tomándose nota de los organismos existentes, del color de la piedra y de los síntomas de alteración. El análisis de estos datos mediante el Test de Chi Cuadrado mostró que la roca más común es la arenisca de color blanco. Aunque no se detectó ninguna evidencia de que T. aurea tuviese preferencia por alguna roca de un color determinado, sí se encontró que había una relación significativa $(\mathrm{P}=0,001)$ entre la presencia de T. aurea y la orientación, siendo mayor la presencia de este alga en las rocas orientadas al norte. El patrón de colonización de T. aurea en la cara norte de la torre noroeste sigue el ascenso capilar, alcanzando varios metros de altura a ambos lados de la torre y descendiendo a aproximadamente $3 \mathrm{~m}$ en el centro de la fachada. Teniendo en cuenta que el terreno cae en pendiente bastante pronunciada hacia la base de la torre noroeste, que debajo de esta torre hay una zanja de drenaje, y que ésta está rellena con tierra suelta hasta una altura de $4 \mathrm{~m}$ por el interior de la pared, se espera que haya un considerable movimiento de agua debido a capilaridad y que éste ayude al desarrollo de la comunidad microbiana. De todas maneras, aunque el nivel freático y la pendiente del terreno puedan explicar en parte la distribución del alga en la fachada norte de la torre noroeste (puesto que la humedad es un factor limitante del crecimiento), es probable que la orientación y el microclima también juegen un papel importante.

De los organismos visibles colonizadores de la cara norte los más abundantes son el liquen Caloplaca citrina, $y^{\prime}$ un organismo de color negro que podría ser una cianobacteria (sin confirmar), seguidos en abundancia por el liquen Tephromela atra y el alga Trentepohlia aurea. Se observó que el organismo negro estaba relacionado con la alteración, especialmente en la cara este del castillo, sin embargo se requieren posteriores investigaciones para conocer el mecanismo de alteración implicado. En la parte inferior del talo de T. atra se encontraron cristales de whewellita y weddellita, lo cual indica la capacidad del liquen para utilizar el Ca libre presente en la roca y el mortero.

\section{DISCUSIÓN Y CONCLUSIONES}

La monohidrocalcita es un mineral muy poco frecuente en el ambiente geológico. Las referencias bibliográficas que se presentan en este trabajo son todas las que hasta el momento están publicadas.

Sapozhnikov et al. (7) fueron los primeros en citar la monohidrocalcita, encontrando este mineral en sedimentos procedentes de un lago de la antigua URSS. Posteriormente, Semenov (8), Stoffers y Fischbeck (9) y Krumbein (10) informaron y discutieron sobre la presencia de cristales trapezoidales de $2-10 \mu \mathrm{m}$ de este such as presence of biological growths, stone colour and decay characteristics. Manipulation of the data using the Chi Square Test showed the most common stone colour was white sandstone. There was no evidence that $T$. aurea preferred any particular stone colour. but a significant relationship (P-value, 0.001) was found between the occurrence of $T$. aurea and aspect suggesting that the proportion of north facing stones with $T$. aurea is higher than for other aspects, in particular south and west. The pattern of growth of $T$. aurea on the north face of the north west tower, followed the pattern of capillary rise. The growth reached several metres in height at the sides of the tower and decreased to approximately 3 metres at the centre of the facade. Considering that the ground sloped steeply down towards the base of the north west tower, and there was a drainage ditch beneath the tower, and that also the interior of the tower was filled with loose earth which reached up to 4 metres on the inside wall, considerable water movement due to capillarity is to be expected which may aid the growth of the microbial community. Although the presence of underground water and sloping ground may explain in part the distribution of the alga on the north tower north west face (since moisture is a limiting factor to growth), it is likely that aspect and microclimate also plays an important part.

The most common organism visible on the north face was the lichen Caloplaca citrina and a black organism thought to be a cyanobacterium (identity unsubstantiated) followed in abundance by the lichen Tephromela atra and the alga T. aurea. The black organism was observed associated with decay, particularly on the west face of the castle, however, further work would be needed to elucidate the precise decay mechanism involved. T. atra had whewellite and weddellite on the undersurface of the thallus indicating an ability to utilise free Ca present in the stone and mortar.

\section{DISCUSSION AND CONCLUSIONS}

Monohydrocalcite is an extremely rare mineral in the geological environment. The references listed in this paper represent published occurrences of monohydrocalcite to date.

\section{Sapozhnikov et al. (7) first reported}

monohydrocalcite in a lake sediment from the former USSR. Later, Semenov (8), Stoffers and Fischbeck (9) and Krumbein (10) reported and discussed 2-10 $\mu \mathrm{m}$ trapezohedral crystals in Lake Kivu in East Africa. 
mineral en el Lago Kivu en el Este de Africa. También se ha citado la presencia de cristales trigonales-trapezoidales en zonas de oxidación inundadas por soluciones con altos valores de $\mathrm{pH}$, soluciones vadosas $\mathrm{Mg} / \mathrm{Ca}$ ricas en oxígeno e iones arseniato (11); en depósitos minerales ricos en cobre en la antigua Checoslovaquia (12) y en escorias de cantera en Alemania (13-15).

Fischbeck y Muller (16) y Broughton (17) discutieron la génesis de la monohidrocalcita en cuevas en Alemania, y Marschner (18) identificó el mineral en filtros de equipos de aire acondicionado y en grifos de agua fría. En condiciones específicas de laboratorio este mineral fue precipitado por cultivos de bacterias heterótrofas marinas y hongos (19), y a partir del agua de mar en condiciones de temperatura ambiente (20).

Los estudios de laboratorio llevados a cabo por Brooks et al. (21) y los estudios termoquímicos de Hull y Turnbull (22) indican que la monohidrocalcita es metaestable con respecto a la calcita y al aragonito.

Existen varias teorías, para las cuales el presente trabajo constituye una importante aportación, que pueden explicar la presencia de este mineral en el 'Hermitage Castle'. Las muestras de roca descamada contenían entre un 0,90 y un $2,02 \%$ de $\mathrm{Ca}$ (datos obtenidos mediante $\mathrm{XRF}$ ); la fuente potencial de este $\mathrm{Ca}$ es el mortero rico en $\mathrm{Ca}(18,23 \%)$, el cual se disuelve y migra hacia el interior de la roca. Sin embargo, nunca se esperaría que este elemento reprecipitase como monohidrocalcita sino como calcita ya que la monohidrocalcita es metaestable con respecto a la calcita y al aragonito tal y como demostraron Hull y Turnbull (22). De todas maneras, hay que tener encuenta que, bajo ciertas condiciones, el $\mathrm{Mg}$ puede inhibir la formación de calcita favoreciendo la formación de monohidrocalcita (22) y en este caso el $\mathrm{Mg}$ está presente tanto en las escamas como en el mortero. Además, el magnesio también es necesario para la producción de clorofila en los organismos fotosintéticos.

La formación de la monohidrocalcita puede estar relacionada con la presencia de organismos vivos mediante diferentes procesos que pueden actuar individual o sinérgicamente. Puesto que el $\mathrm{Ca}$ es el elemento mineral más vulnerable a ser quelado por compuestos orgánicos (23), su acumulación puede ser indicativa de un proceso de quelación mediado biológicamente donde la comunidad biológica reorganiza el Ca para formar monohidrocalcita biogénica. Sin embargo, se reconoce que en este trabajo no se puede explicar la génesis precisa de la monohidrocalcita y que es necesario continuar la investigación en esta línea.

En lo que se refiere a la nesquehonita y dipingita, se citan a continuación las referencias bibliográficas que existen
Trigonal-trapezohedral crystals have also been reported in oxidation zones flushed by high $\mathrm{pH}$, $\mathrm{Mg} / \mathrm{Ca}$ vadose solutions enriched in air and arsenate ions (11); in copper rich ore deposits in former Czechoslovakia (12) and in quarry slags in Germany (13-15).

Fischbeck and Muller (16) and Broughton (17) discussed the genesis of monohydrocalcite in speleotherms in Germany and Marschner (18) identified the mineral in scrubbers of air conditioning plants and in cold water taps. The mineral has been precipitated in cultures by marine heterotrophic bacteria and fungi, under specific laboratory conditions (19) and from seawater at room temperatures (20).

Laboratory studies by Brooks et al. (21) and thermochemical studies by Hull and Turnbull (22) indicate that monohydrocalcite is metastable with respect to calcite and aragonite.

There are various theories, for which the current literature provides valuable input, that may account for the occurrence of this mineral at Hermitage Castle. The samples of spalled stone contained between 0.90 and $2.02 \% \mathrm{Ca}$ (XRF data). The original $\mathrm{Ca}$ source is potentially dissolution of the high $\mathrm{Ca}$ $(18.23 \%)$ lime mortar which then migrates into the stone. However one would not normally expect a Ca reprecipitate to be monohydrocalcite, calcite is more likely, as monohydrocalcite is metastable with respect to calcite and aragonite as shown by Hull and Turnbull (22). However in certain circumstances $\mathrm{Mg}$ can inhibit the formation of calcite in preference to monohydrocalcite (22) and $\mathrm{Mg}$ is present in the spall and in mortar from Hermitage Castle.

The monohydrocalcite associated with the biological community maybe due to a variety of processes acting singly or synergistically. As Ca is the most vulnerable of the mineral elements to be chelated by organic compounds (23), its apparent accumulation may also be indicative of a bio-mediated chelation process where the biological community re-works the $\mathrm{Ca}$ to form biogenic monohydrocalcite. It is recognised however that the precise genesis of monohydrocalcite cannot be substantiated within the confines of this study and further research would be required to substantiate this hypothesis.

The references listed here represent published occurrences of nesquehonite and dypingite to date. 
hasta el momento sobre estos minerales. La

Nesquehonita fue citada por primera vez por Genth y Penfield en 1980 (24) a partir de muestras de mina, y descrita por Fenoglio en 1935 (25). En 1969

Montgomery (26) publicó fotografias de este mineral. Brusse y Guerin (27) lo citan, en Francia, como una costra blanca en sedimentos. También se encontró en sedimentos lacustres y en cuevas $(16,28)$.

Marschner (18) cita la presencia de nesquehonita en precipitados en grifos de agua fría y en "moonmilk" de cuevas, sugiriendo Broughton (17) un posible origen biogénico. En 1970, Towe y Malone (20) precipitaron nesquehonita a partir del agua de mar. La solubilidad, descomposición termal de nesquehonita a magnesita, así como su estabilidad fueron estudiadas por Harvie et al. (29), Dell y Weller (30), Langmuir (31), Iwal et al. (32) y Robie y Hemingway (33); su caracterización por infra-rojos fue realizada por White (34).

En cuanto a la dipingita, este mineral raramente se ve en la naturaleza. Canterford et al. en 1984 (35) describieron una sintética cristalina, en forma de polvillo, muy fino y blanco.

Es posible que el mineral encontrado en la roca del interior del 'Hermitage Castle' fuese dipingita o landsfordita, el cual posteriormente se deshidrató dando lugar a nesquehonita (fenómeno citado por Ming (6)). De todas maneras, la génesis de estos minerales en el caso concreto del 'Hermitage Castle' necesita seguir siendo investigada para su posterior confirmación.

En la roca alterada procedente del 'Hermitage Castle' el calcio está presente en varias formas, tales como la monohidrocalcita, $y$, aunque la presencia de calcio "per se" no implica ningún peligro para la integridad de la roca, sí ayuda al mantenimiento de la comunidad biológica ya que ésta utiliza Ca para sus procesos metabólicos. Los organismos vivos alteran la roca, principalmente por mecanismos bio-fisicos, así, en el caso de T. aurea éstos ocurren debido al desarrollo celular y a la expansión del mucílago, provocada por los ciclos de humedad y secado. Estos mecanismos serán objeto de próximos trabajos.

\section{AGRADECIMIEINTOS}

Este trabajo se enmarca dentro de un estudio más amplio titulado "Biodeterioration of Sandstone by Algae and Application of Stone Methods", el cual fue realizado con fondos procedentes del UK Engineering and Physical Research Council (Grant Reference GRJ91500) (Jones and Wakefield et al., 1996 unpublised).

Nuestro agradecimiento también al Historic Scotland, por permitir el acceso al Hermitage Castle y a M. Young, por la ayuda prestada con el porosímetro de mercurio.
Nesquehonite was first named in 1890 from mine samples by Genth and Penfield (24) and described by Fenoglio in 1935 (25). Photographs were published in 1969 by Montgomery (26). White encrustations in brecciated sediments in France have been reported by Brousse and Guerin (27). Nesquehonite has also been found in lacustrine sediments and in speleothems $(16,28)$.

\section{Marschner (18) reported nesquehonite in} precipitates in cold water taps and in "moonmilk" from caves where a bacterial biogenic origin was also suggested by Broughton, (17). Seawater precipitates of nesquehonite were produced by Towe and Malone in 1970 (20). The solubility, thermal decomposition of nesquehonite to magnesite, and its stability have been studied by Harvie et al. (29), Dell and Weller (30) Langmuir (31), Iwal et al. (32) and Robie and Hemingway (33) and its Infra-red characterisation by White (34).

Snow-white finely crystalline man made dypingite was described by Canterford et al. in 1984 (35) and is rarely found to occur naturally.

It is possible that the mineral material found on Hermitage stone in the interior of the castle was dypingite or landsfordite which subsequently dehydrated to nesquehonite (a phenomena reported by Ming (6)). However the genesis of these minerals at Hermitage Castle cannot be substantiated within the confines of this study and further work is required.

Calcium in various forms such as monohydrocalcite is present in decayed stone taken from Hermitage Castle. Although the presence of Ca "per se" does not harm the stone integrity it helps support the biological community which utilises Ca for its metabolic processes. The biological community then causes damage to the stone mainly by bio-physical decay mechanisms such as T. aurea cell expansion and growth and mucilage expansion due to wet/dry cycling. These mechanisms will be the subject of a further paper.

\section{ACKNOWLEDGMENTS}

Funding was obtained from the UK Engineering and Physical Research Council, (EPSRC) for a two year study (1994-96) entitled Biodeterioration of Sandstone by Algae and Application of Stone Conservation Methods (Grant Reference GRJ91500) (Jones and Wakefield et al., 1996 unpublised).

To Historic Scotland for access to Hermitage Castle and $M$. Young for aiding with the mercury porosimetry. 


\section{BIBLIOGRAFÍA}

(1) R.D. WAKEFIELD, M.S.JONES, M.E YOUNG, K. NICHOLSON, D. URQUHART, M.J. WILSON: Investigations of decayed sandstone colonised by a species of Trentepohlia. Aerobiologia, Vol. 12(1996), pp. 19-25.

(2) R.D. WAKEFIELD, M.S. JONES, G. FORSYTH: Decay of sandstone colonised by an epilithic algal community. pp. 88-97. In Processes of Urban Decay, Editors, B.J. Smith, P.A. Warke, Donhead. ISBN 187339420 9, 1996.

(3) M.S. JONES, R.D. WAKEFIELD, G. FORSYTH: Biodeterioration of sandstone colonised by algae and stone conservation methods. EPSRC final report, unpublished. Grant Reference GRJ91500. 1996.

(4) W.S. LOH, K.T. LEE: Factors contributing to the fouling of walls on Singapore buildings by algal growth. In: Fourth International Conference Durability of Building and Components, Singapore(1987), pp. 1040-1048.

(5) M.S. JONES, R.D. WAKEFIELD: Materials methodologies and techniques associated with a study of biodeterioration at Hermitage Castle, United Kingdom. Proceedings of a U.N. IGCP workshop Czech Republic, Brno (1996), pp. 107-115.

(6) D.W.MING, W.T. FRANKLIN: Synthesis and characterisation of landsfordite and nesquehonite. Soil Sci. Soc. Am. J. Vol. 49(1985) pp. 1303-08.

(7) M.FLEISCHER:Occurences of $\mathrm{CaCO}_{3} \cdot \mathrm{H}_{2} \mathrm{O}$ and itsnaming. Science, Vol. 166(1969) 1309 \{ibid Sapozhnikov etal Dokl.Akad. Nauk SSSR. Vol. 124(1959) 402\}.

(8) E.I. SEMENOV: On hydrous carbonates of calcium and sodium. Kristallografiya. Vol. 9(1964), pp. 109-110.

(9) P. STOFFERS, R. FISCHBECK: Monohydrocalcite in the sediments of Lake Kivu (East Africa) Sedimentology.Vol.21 (1974), pp. 163-70.

(10) W.E. KRUMBEIN: Biogenic monohydrocalcite spherules in the lake sediments of Lake Kivu, Africa and the Solar Lake (Sinai) Sedimentology. Vol. 22(1975)pp.631-34.

(11) J. MINCEVA-STEFANOVA, H. NEYKOV: Comptes Rendus de l’ Academie Bulgare des Sciences. Vol. 43, nº 2(1990), pp. 57-60.

(12) T. RIDKOSIL, J. SEJKORA, P. ONDRUS: Trigonal-trapezohedral mono-hydrocalcite from an oxidation zone. Neus Jahrbuch fur Minewalogie, Monatshefte. Vol. 7(1991),pp. 289-295.

(13) G. SCHNORRER-KOHLER, P. RAMSBECK: Trigonal-trapezohedral monohydrocalcite froman oxidation zone, Aufschluss, Vol. 41, n?4,(1990), pp. 211-218.

(14) G. SCHNORRER-KOHLER: Mineralogische Notizen V.I. Aufschluss. Vol. 42, n 3 (1991), pp. 151-171.

(15) G. SCHNORRER-KOHLER: Monohydrocalcite in slags from quarrys in the Harz Mts, Germany (translation). Aufschluss. Vol. 44, $\mathrm{n}^{0} 1$ (1993), pp. 44-58.

(16) R.FISCHBECK, G. MULLER: Monohydrocalcite, hydromagneste, nesquehonite, dolomite, aragonite and calcite in speleothems of the Frankische Schweiz, Western Germany. Contrib. Mineral. and Petrol. Vol. 33 (1971), pp. 87-92.

(17) P.LBROUGHTON: Monohydrocalcite in speleothems: an alternative interpretation, Contr. Mineral. and Petrol. Vol. 36, (1972), pp. 171-74.

(18) H.MARSCHNER: Hydrocalcite $\left(\mathrm{CaCO}_{3} \cdot \mathrm{H}_{2} \mathrm{O}\right)$ and nesquehonite $\left(\mathrm{MgCO}_{3} \cdot 3 \mathrm{H} 2 \mathrm{O}\right)$ in carbonate scales, Science, Vol. $165(1967)$, pp. 1119-21.

(19) W.E. KRUMBEIN: On the precipitation of aragonite on the surface of marine bacteria. Naturwissenschaften.Vol. 61 (1974), 167.

(20) K.M. TOWE, P.G. MALONE: Precipitation of metastable carbonates phases from seawater. Nature, Vol. 226 (1970), pp. $348-349$.

(21) R. BROOKS, L.M. CLARK, E.F. THURSTON: Calcium carbonate and its hydrates. Phil. Trans. Royal Society London. Vol. 243 (1951), pp. 145-67.

(22) H.HULL, A.G. TURNBULL: A thermochemical study of monohydrocalcite. Geochimica et Cosmochimica Acta. Vol. 37(1973), pp. 685-94. 
(23) B.S. LEADBETTER, R. RIDING: Biomineralisation in plants and lower animals. The Systematics Association, Special Vol. 30 , Clarendon Press, Oxford, 1986.

(24) F.A. GENTH, S.L. PENFIELD: Uber landsfordit, nesquehonit (ein neues Mineral) und pseudomorphosen von nesquehonit nach lansfordit. Mem. de la Soc de Phys. et d'Hist. Vol. 14, nº 252 (1890), pp. 560-77.

(25) M.FENOGLIO: Ricerche sulla nesquehonite delle miniere di cogne in Val d'Aosta. Periodico di Mineralogia, Vol. 6(1935-XIII), pp. $1-17$.

(26) A. MONTGOMERY: The mineralogy of Pennsylvania. Philadelphia Acad. Natur. Sci Spec. Publ. 9. 1969.

(27) R. BROUSSE, H. GUERIN: Plaques de nesquehonite sur las breche du Cantal Bull. Soc. Franc. Min. Crist. Vol. 89, (1966), pp. 281282.

(28) G. MULLER G. IRION, U. FORSTNER: Formation and diagnosis of inorganic Ca-Mg carbonates in the lacustrine environment. Naturwissenschaften. Vol.59(1972), pp. 158-64.

(29) C.E. HARVIE, N. MOLLER, J.H. WEARE: The prediction of mineral solubilites in natural waters: the Na-K-Mg-Ca-H-Cl-SQOH$\mathrm{HCO}_{3}-\mathrm{CO}_{3}-\mathrm{CO}_{2}-\mathrm{H}_{2} 0$ system to high ionic strenghts at $25^{\circ} \mathrm{C}$. Geochimica et Cosmochimica Acta. Vol. 48 (1984), pp. 723-51.

(30) R.M. DELL, S.W. WELLER: The thermal decomposition of nesquehonite $\mathrm{MgCO}_{3} \cdot 3 \mathrm{H}_{2} \mathrm{O}$ and magnesium ammonium carbonate $\left(\mathrm{MgCO}_{3} \cdot(\mathrm{NH} 4)_{2} \mathrm{CO}_{3} \cdot 4 \mathrm{H}_{2} \mathrm{O}\right.$. Trans. Faraday Soc. Vol. 55 (1959), pp. 2203-2220.

(31) D. LANGMUIR: Stability of carbonates in the system $\mathrm{MgO}-\mathrm{CO}_{2}-\mathrm{H}_{2} \mathrm{O}$. Jour. Geol. Vol. 73 (1965), pp. 730-54.

(32) S.W. IWAL, Y. SOTOME, H. MORIKAWA: Reactions of magnesium carbonate by direct $x$-ray diffraction under hydrothermal conditions. Amer. Min. Vol. 56(1971), pp. 628-629.

(33) R.A. ROBIE, B.S. HEMINGWAY: The heat capacities at low temperatures and entrophies at 298.15K of nesquehonite, and hydromagnesite Am. Mineralogist, Vol. 57(1972), pp. 1768-81.

(34) W.B. WHITE: Infrared characterisation of water and hydroxyl ion in the basic magnesium carbonate minerals. Amer. Min., Vol. 56 (1971),pp. 46-53.

(35) J.H.CANTERFORD, G. TSAMBOURAKIS, B. LAMBERT: Some observations on the properties of dypingite, $\mathrm{Mg}_{5}\left(\mathrm{CO}_{3}\right)_{4}\left(\mathrm{OH}_{2} \cdot 5 \mathrm{H}_{2} \mathrm{O}\right.$, and related minerals. Min. Mag. Vol. 48 (1984), pp. 437-42. 